Bulletin of the Natural History Museum, 2018, 11: 227-245.

Received 02 Sep 2018; Accepted 02 Dec 2018.

doi:10.5937/bnhmb1811227U

UDC: 597.851(497.11)

Original scientific paper

\title{
DISTRIBUTION AND DIVERSITY OF BROWN FROGS (RANA SPP., ANURA, AMPHIBIA) IN SERBIA
}

ALEKSANDAR UROŠEVIĆ ${ }^{1 *}$, LJILJANA TOMOVIĆ ${ }^{2}$, IMRE KRIZMANIĆ2, MARKO ANĐELKOVIĆ ${ }^{1}$, ANA GOLUBOVIĆ ${ }^{2}$, MARKO MARIČIĆ ${ }^{3}$, RASTKO AJTIĆ ${ }^{4}$, JELENA ĆOROVIĆ ${ }^{1}$, TIJANA ČUBRIĆ ${ }^{\text {, NATAŠA TOMAŠEVIĆ- }}$ KOLAROV $^{1}$, Milena CVIJANOVIĆ ${ }^{1}$, TANJA VUKOV ${ }^{1}$, BOGDAN JOVANOVIĆ ${ }^{1}$, TIJANA VUČIĆ ${ }^{2}$, MAJA AJDUKOVIĆ ${ }^{1}$, IVAN TOT ${ }^{6}$, BOJANA NADAŽDIN ${ }^{6}$, NENAD LABUS ${ }^{7}$, GEORG DŽUKIĆ ${ }^{1}$

${ }^{1}$ University of Belgrade, Institute for Biological Research "Siniša Stanković", Bulevar Despota Stefana 142, 11000 Belgrade, Serbia,

${ }^{2}$ University of Belgrade, Faculty of Biology, Institute of Zoology, Studentski trg 16, 11000 Belgrade, Serbia

${ }^{3}$ Scientific Research Society of Biology and Ecology Students "Josif Pančić", Trg Dositeja Obradovića 2, 21000 Novi Sad, Serbia

${ }^{4}$ Institute for Nature Conservation of Serbia, Dr Ivana Ribara 91, 11070 Belgrade, Serbia.

${ }^{5}$ University of Niš, Department of Biology and Ecology, Faculty of Sciences and Mathematics, Višegradska 33, 18000 Niš, Serbia

${ }^{6}$ Association for Sustainable Development and Habitat Protection in Serbia "HabiProt", Bulevar Oslobođenja 106/34, 11040 Belgrade, Serbia

${ }^{7}$ University of Priština, Faculty of Science and Mathematics, Biology Department, Lole Ribara 29, 38220 Kosovska Mitrovica, Serbia

In this study, we present updated distribution data for all three brown frog species (Rana spp.) inhabiting Serbia. The data provided consists of newly 
collected field records and compiled data previously published in literature or via Internet. Of the three species found in Serbia, Rana dalmatina is the most widespread, present in all three altitudinal regions and all biogeographical regions. Rana graeca is confined to Mountain-valley altitudinal region in permanent fastflowing rivers or streams and it reaches its northern range boundaries in Serbia. Rana temporaria is the rarest of the three, with fragmented range restricted to the high mountains or few isolated lowland populations, and in the north-eastern Serbia, it is vicariant with $R$. graeca in canyons and gorges of montane rivers. The presence of Rana arvalis in Serbia is mentioned in literature but was not confirmed during the subsequent field surveys, so we consider it only as a potential species for the Serbian batrachofauna. The brown frog faunal composition of Serbia is identical to that of Albania, Bosnia and Herzegovina, Bulgaria, Greece, Macedonia and Montenegro, while it is somewhat different from that of Hungary and Romania and the most different from Croatia and Slovenia. Serbian brown frogs belong to European ( $R$. temporaria) and South-European ( $R$. dalmatina, $R$. graeca) chorotypes. All species of brown frogs present or potentially present in Serbia and their habitats are identified as great conservation priorities.

Keywords: Distribution, diversity, Rana, zoogeography

\section{INTRODUCTION}

Reporting of precise and accurate specimen sightings is paramount in biogeographical studies (Wallace 1852, Meiri 2018). During the last decade, the number of studies on herpetofaunal distribution and diversity in the Balkans has exponentially grown (Cogălniceanu et al. 2013a, 2013b, Vukov et al. 2013, Sterijovski et al. 2014, Tomović et al. 2014, 2015, 2018, Krizmanić et al. 2015, Ljubisavljević et al. 2014, 2015, 2016, 2018, Urošević et al. 2015, 2016, Szabolcs et al. 2017). Such studies provide data needed as a basis for the conservation purposes (implementation of Natura 2000 network, estimation of the conservation status for national Red Lists and Red Books), ecological, evolutionary or systematic research of certain taxa or biogeographical studies in broader context (Jetz et al. 2011, Zachos \& Habel 2011) as well as faunal taxonomic distinctiveness (Warwick \& Clarke 1995, Clarke \& Warwick 1999). As the Balkan Peninsula is recognized as one of the main European centres of endemism and speciation (Gaston \& David 1994, Džukić 1995, Džukić \& Kalezić 2004) such studies are of great importance on all taxonomic levels. The whole Balkan Peninsula was also an important glacial refugium during the Pleistocene, and one of the sources for the subsequent recolonisation of Europe (Guillaume et al. 1997, Džukić \& Kalezić 2004, Böhme et al. 2007). Since Serbia is situated in the central parts of the Balkan Peninsula, 
it can be viewed as a transitional zone, with various biogeographic phenomena being observed (Džukić \& Kalezić 2004).

Brown frogs (Rana spp.) also known as the true frogs are a group of species ranging throughout the Palaearctic and sharing similar morphology - medium size, prominent dorsolateral folds, brown colour and dark facial masks (Green \& Borkin 1993). These frogs are mostly terrestrial, quietvoiced and tend to be early spring explosive breeders (Arnold \& Ovenden 2002). The distribution pattern of Palaearctic brown frogs is specific, with some species widespread throughout Europe and Eurasia (two of them reaching Arctic Circle), and others being endemics restricted to specific habitats in the Iberian, Apennine and Balkan Peninsulas and Asia Minor (Veith et al. 2003). Rana arvalis morphologically and ecologically fits well in this group. It has a reduced set of chromosomes, 24 contrary to the typical 26 of the $R$. temporaria group (Green 1983, Mensi et al. 1992, Green \& Borkin 1993). However, more recent molecular studies of the Western Palaearctic brown frogs showed that $R$. arvalis is closely related to $R$. temporaria and that Western Palaearctic brown frogs are indeed a monophyletic group (Veith et al. 2003). This group went through a process of adaptive radiation into five major clades about four million years ago, and southern mountain endemics, such as $R$. graeca most likely originated from populations which remained "trapped" in their glacial refugia (Veith et al. 2003).

The published information on brown frog species inhabiting Serbia is relatively scarce (Karaman 1948, Radovanović 1951, Pasuljević 1966, Džukić 1968, Džukić 1972, Džukić \& Pasuljević 1979, Tadijan \& Mikeš 1984, Perić \& Stanković 2005, Ivančević et al. 2007, Crnobrnja-Isailović et al. 2012, Sterijovski 2014) and often restricted to findings of single, extralimital populations (Džukić 2004). The studies presenting confirmed and potential distribution ranges in Serbia (Vukov et al. 2013) do not provide precise spatial data or georeferenced localities.

The aim of this study is to provide a survey of the known distribution of brown frogs in Serbia, georeference data at the $10 \times 10 \mathrm{~km}$ standardized UTM grid and analyze diversity patterns.

\section{MATERIALS AND METHODS}

We gathered data from published literature records (60), published data from the Batrachological Collection of the Institute for the Biological Research "Siniša Stanković" (242), verifiable online records from field herpetology and biodiversity websites (157) and previously unpublished field observations gathered by co-authors (626). All unpublished field data 
are listed with locality names in Appendix 1. The complete list of literature records, including the Batrachological Collection, is given in the Appendix 2. In the case of still unconfirmed species for Serbia, we treated literature record without later verification in the field as doubtful. When using data from the Internet, namely websites Balcanica (Balej \& Jablonski 2015), iNaturalist (iNaturalist.org 2018a, 2018b), Bioras (Mesaroš, 2018) and Biologer (Maričić \& Golubović 2018) we complied with terms and conditions of websites, and asked site administrators and contributors for permissions to cite their entries. The complete website data with individual citations and authorship for each entry are provided in Appendix 3.

The studied species were identified according to standard herpetological literature, by visual inspection of diagnostic characters on preserved specimens, in voucher photographs or in the field (Arnold \& Ovenden 2002). For the species with specific habitat requirements (e.g. $R$. graeca, $R$. temporaria) recognition of adequate habitats or their fragments was essential for finding and identification of animals (Radovanović 1951, Džukić 1968, Arnold \& Ovenden 2002).

All entries were mapped in the $10 \times 10 \mathrm{~km}$ UTM (Universal Transverse Mercator) geographic coordinate grid system to facilitate interpretation of our maps and avoid sampling bias. Because of the lack of systematic efforts to cover all territory of Serbia, lack of records of certain species from some areas does not necessarily imply their physical absence.

Species richness of brown frogs was assessed on a regional level, according to the main altitudinal and biogeographical regions. The territory of Serbia encompasses three altitudinal regions: (1) parts of the Great Pannonian plain in the Vojvodina province in the north (0-200 $\mathrm{m}$ a.s.1.), (2) the Peripannonian lowlands and hills along southern banks of the Sava and Danube rivers and in the Velika Morava River valley (200-600 m a.s.1.), and (3) the Mountain-valley region (600-2,650 m a.s.1.) (Marković 1970) (Fig. 1). The recognized biogeographic regions of Serbia according to Marković 1970 and Stevanović 1992 are: Bačka (Ba), Banat (Bt), Srem

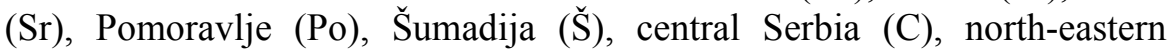
Serbia (NE), eastern Serbia (E), north-western Serbia (NW), south-eastern Serbia (SE), western Serbia (W), south-western Serbia (SW), southern Serbia (S), Kosovo (K), and Metohija (M) (Fig. 1).

Also, we evaluated similarities between Serbia and the neighbouring countries, using the Bray-Curtis dissimilarity index (Bray \& Curtis 1957). Species distribution and diversity data for Albania, Bosnia and Herzegovina, Bulgaria, Croatia, Greece, Macedonia, Hungary, Montenegro, Romania and Slovenia were given according to the contemporary literature (Gasc et al. 1997, Jablonski et al. 2012, Cogălniceanu et al. 2013a, Sillero et al. 2014). 
For the zoogeographic analysis, chorotypes of brown frogs were identified, according to Vigna Taglianti et al. (1999).

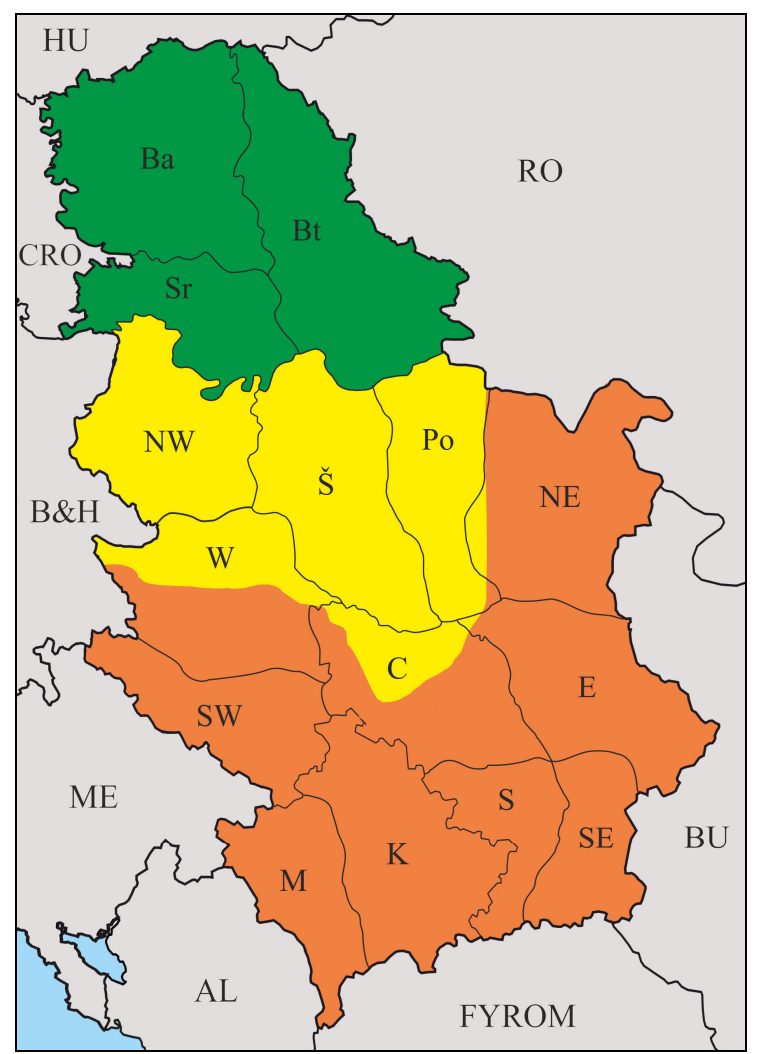

Fig. 1. - Altitudinal and biogeographic regions of Serbia. Altitudinal regions: green - Pannonian, yellow - Peripannonian, orange - MountainValley. Biogeographic regions: Bč - Bačka, Bt Banat, $\mathrm{Sr}$ - Srem, Po - Pomoravlje, $\breve{S}$ - Šumadija, C. - central Serbia, NE - north-eastern Serbia, NW - north-western Serbia, E - eastern Serbia, W - western Serbia, SE - south-eastern Serbia, SW - south-western Serbia, S - southern Serbia, $\mathrm{K}-$ Kosovo and $\mathrm{M}$ - Metohija.

\section{RESULTS}

The list of brown frogs that inhabit Serbia includes three species. Of these three species, the Agile frog, Rana dalmatina is the most widespread, and its presence has been confirmed in all biogeographic regions (Fig. 2). 


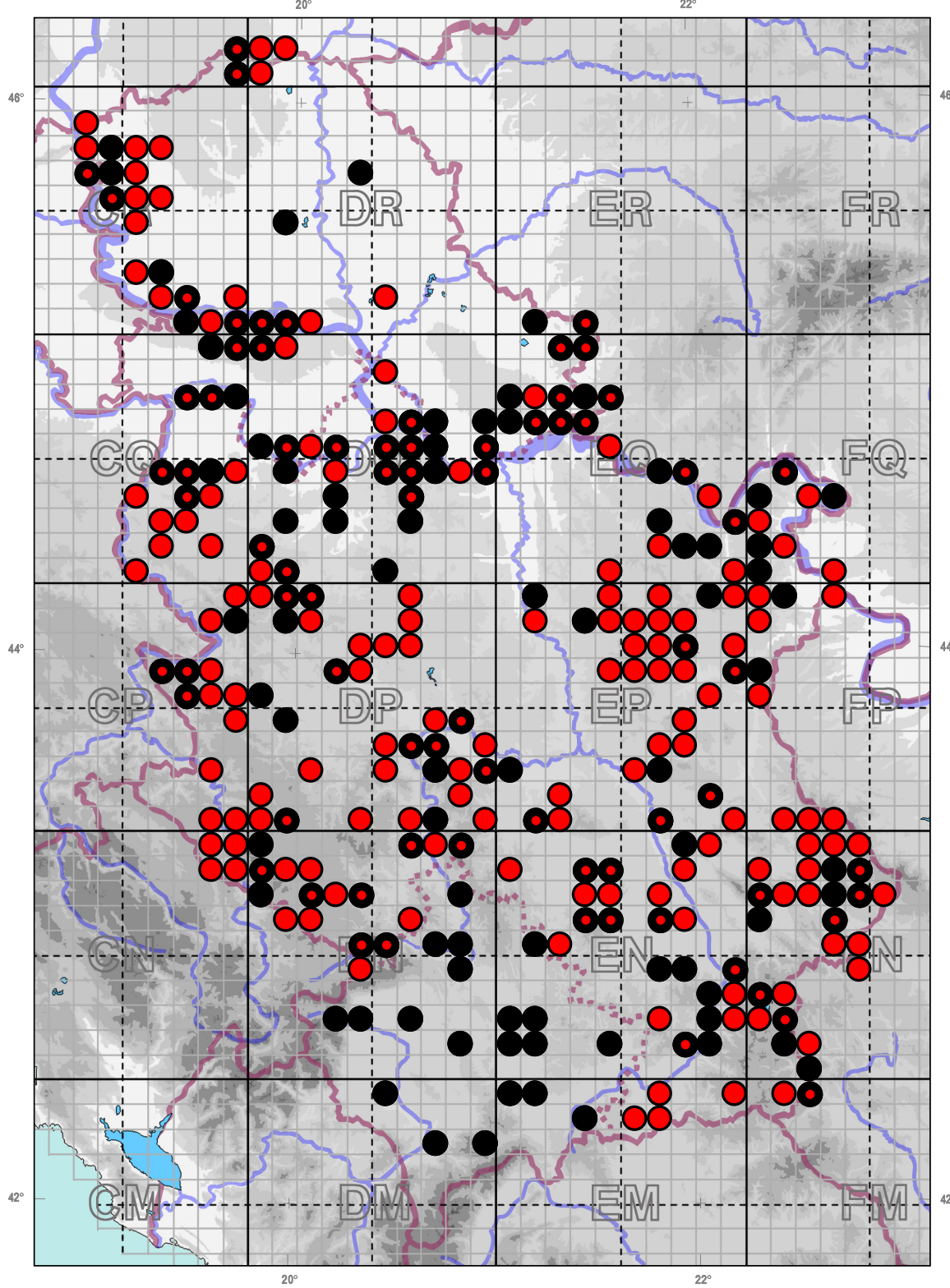

Fig. 2. - Records of $R$. dalmatina from Serbia (National grid UTM $10 \times 10 \mathrm{~km}$ Reference). black circles - published records, red circles - new (field) records, concentric red and black circles - published and field data.

The Balkan stream frog, $R$. graeca is roughly confined to the Mountainvalley parts of Serbia, apart from some populations that reach Peripannonia 
in north-western Serbia and Šumadija. In the eastern parts of Serbia, its distribution limits are further south, reaching Suva Planina mountain (Fig. 3).

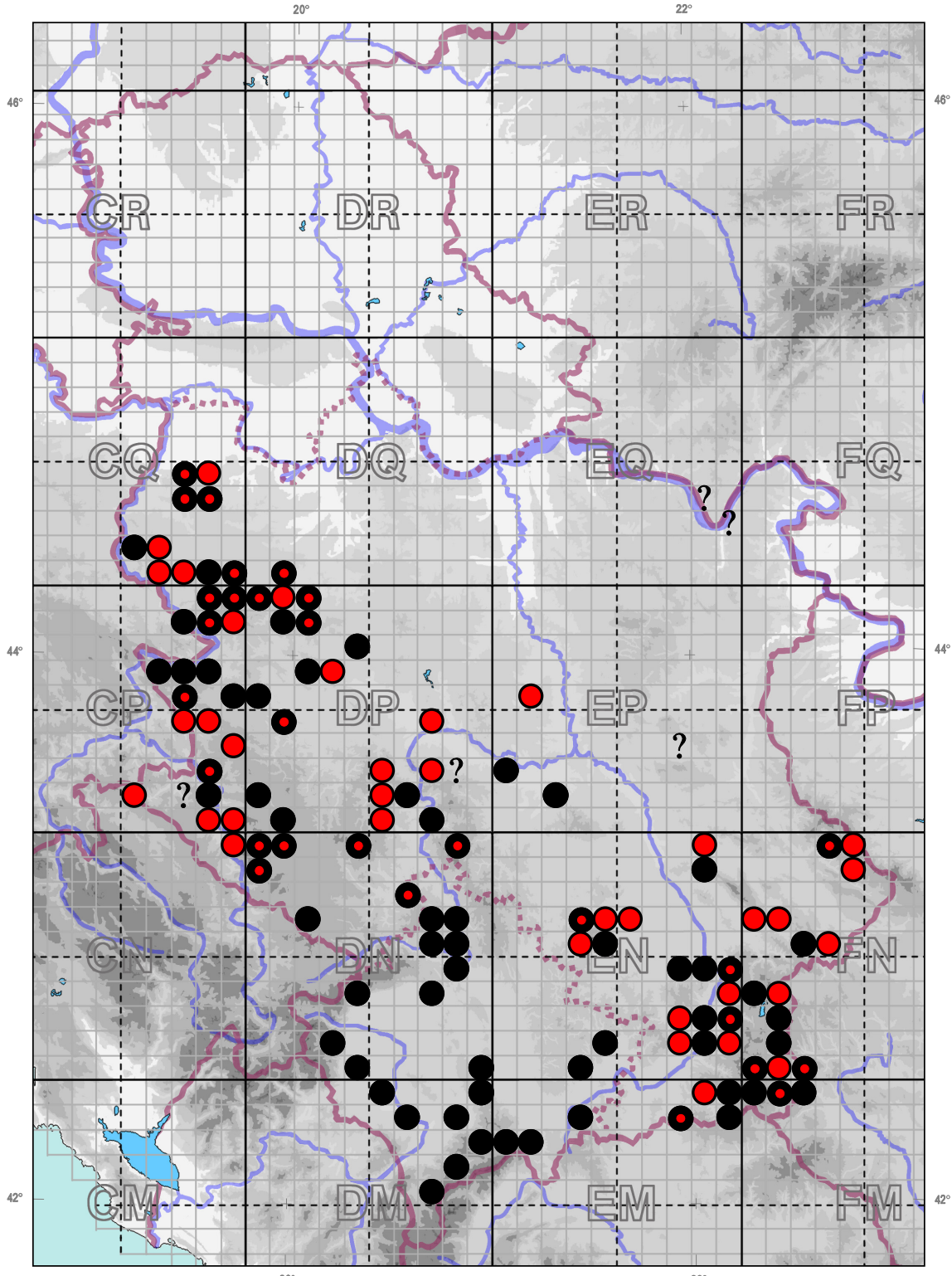

Fig. 3. - Records of $R$. graeca from Serbia (National grid UTM $10 \times 10 \mathrm{~km}$ Reference). black circles - published records, red circles - new (field) records, concentric red and black circles - published and field data, ? - doubtful field or literature data.

Common frog, $R$. temporaria is the rarest of the three species present in Serbia, and its range is highly fragmented, mostly restricted to the 
subalpine and alpine habitats in high mountains, but there are populations in north-eastern and north-western Serbia that inhabit canyons and gorges of montane rivers at lower altitudes, and scattered lowland populations have been detected in the southern Banat (Fig. 4).

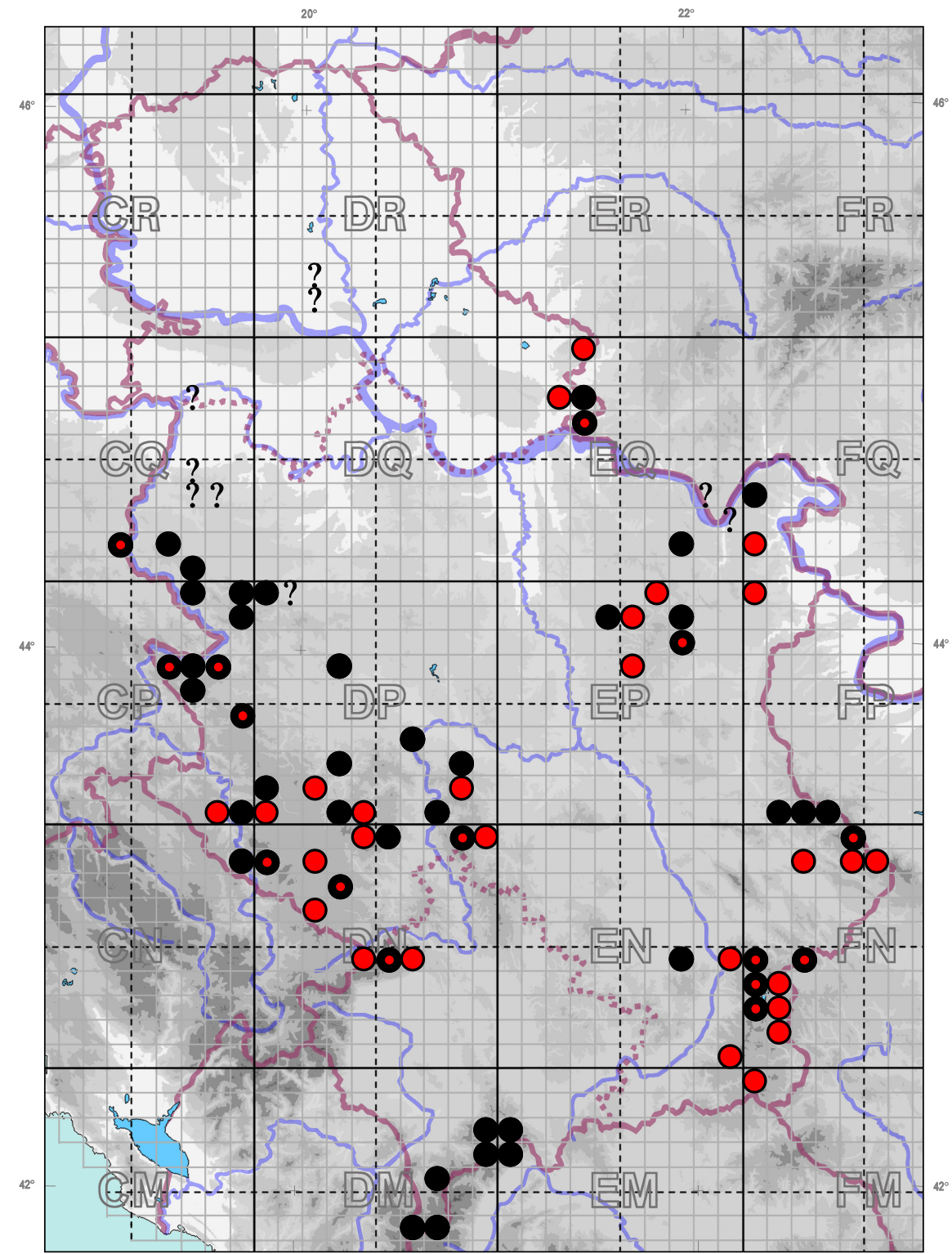

Fig. 4. - Records of $R$. temporaria from Serbia (National grid UTM $10 \times 10$ $\mathrm{km}$ Reference). black circles - published records, red circles - new (field) records, concentric red and black circles - published and field data, ? doubtful field or literature data. 
According to the Bray-Curtis index, the brown frog faunal composition of Serbia is identical to that of Albania, Bosnia and Herzegovina, Bulgaria, Greece, Macedonia and Montenegro. The faunas of Romania and Hungary are more distinct due to the presence of $R$. arvalis and the absence of $R$. graeca. Slovenia and Croatia have the brown frog faunas that are the most different from Serbian, due to the absence of $R$. graeca and presence of $R$. arvalis and $R$. latastei (Fig. 5).

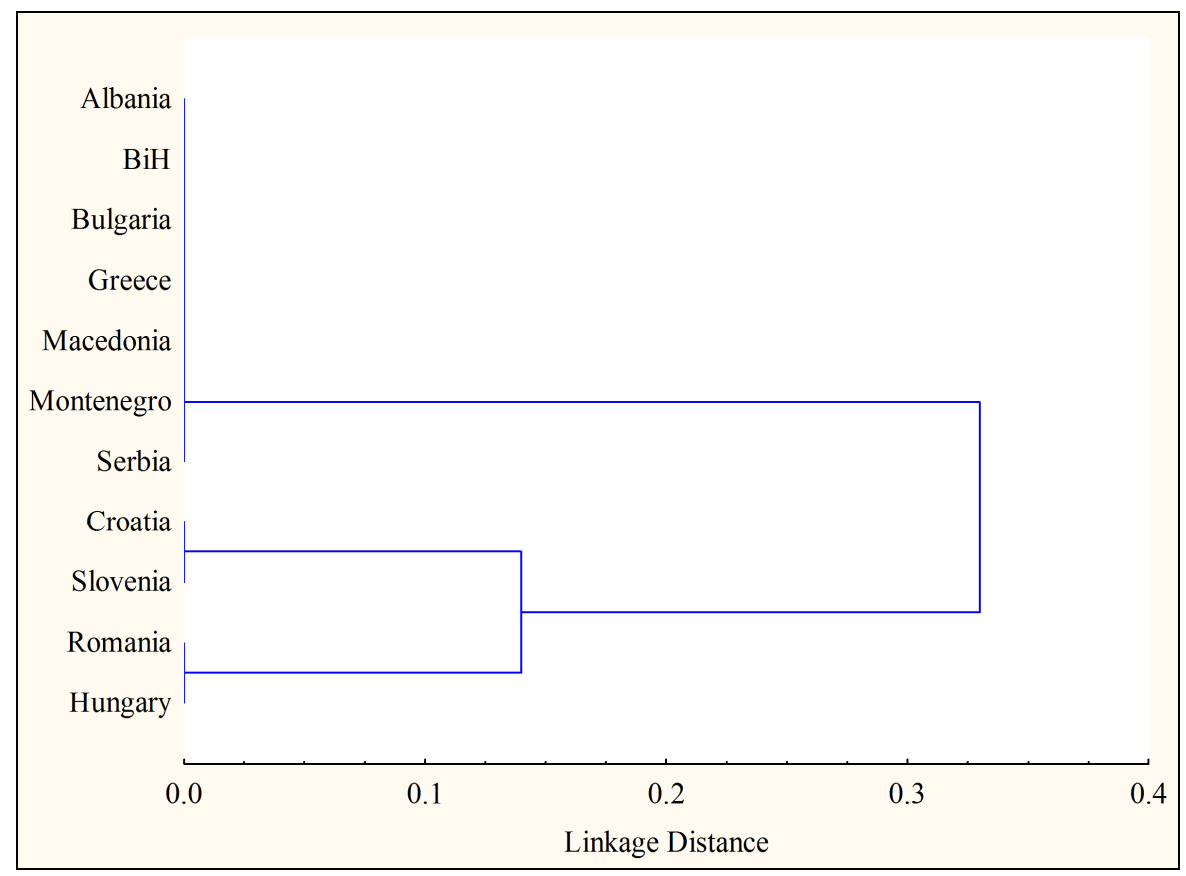

Fig. 5. - Cluster diagram of Bray-Curtis similarity Index of brown frog fauna for the neighbouring countries.

Brown frogs in Serbia belong to two chorotypes, European $(R$. temporaria) and South-European ( $R$. dalmatina, $R$. graeca). Rana graeca is endemic for the Balkans and reaches its northern distribution limits in Serbia, while $R$. temporaria has a fragmented range in Serbia (Tab. 1).

Table 1. - Species list of Serbian brown frogs with chorotype, marginality, endemicity status for Balkans and range fragmentation.

\begin{tabular}{lllll}
\hline \multicolumn{1}{c}{ Species } & Chorotype & Marginal zone & Endemic for the Balkans & Fragmented \\
\hline Rana dalmatina & South-European & & & \\
Rana graeca & South-European & & + & + \\
Rana temporaria & European & + & \\
\hline
\end{tabular}




\section{DISCUSSION}

Agile frog ( $R$. dalmatina) inhabits parts of the Western and Central Europe, Apennine and Balkan peninsulas and northern Asia Minor (Arnold $\&$ Ovenden, 2002). In Serbia, it is the most common and widespread brown frog, which can be found in all three altitudinal regions - Pannonian, Peripannonian and Mountain-valley, and also the only species commonly found in the Pannonian and Peripannonian regions. It is found mostly in open deciduous forests and damp meadows but also in all habitats with suitable shallow or ephemeral ponds, including steppe fragments, rural habitats, parks and edges of agricultural land. It is an explosive breeder in early spring, emerging as soon as mid-February and spawning in shallow water (Radovanović, 1951). It is terrestrial throughout the rest of the year and can be found very far from water. The map shows that this species is evenly distributed throughout Serbia, and distribution gaps can be interpreted more as a result of lack of systematic faunistic research rather than inferred absence of the species.

The Balkan stream frog ( $R$. graeca) is endemic to the Balkan Peninsula, with distribution range from central Bosnia and Herzegovina in the west, through Serbia, Montenegro, Macedonia, Albania, Greece, and southern Bulgaria, to Turkish Thrace in the east (Nöllert \& Nöllert 1992, Asimakopoulos 2004). In Serbia, it is widely distributed in the Mountainvalley region, between 200 and $1000 \mathrm{~m}$ a.s.l. (Radovanović 1951, 1964, Vukov et al. 2013). The Balkan stream frog typically inhabits permanent, fast-flowing streams, springs or small rivers with sparse vegetation in deciduous or mixed forests (Radovanović 1951, Arnold \& Ovenden 2002). It prefers relatively cold and moist microclimate while avoiding regions with long, cold winters and regions with dry and warm climate. The reproductive period usually lasts from February to April (Valakos et al. 2008).

The Common frog (R. temporaria) is distributed throughout Europe, from northern Spain in the west to the Urals and western Siberia in the east (Nöllert \& Nöllert 1992, Grossenbacher 2004) with altitudinal distribution that ranges from the sea level (in northern portions of the range) to $2760 \mathrm{~m}$ a.s.l. (Sindaco et al. 2006). Its distribution in the Balkan Peninsula is disjunct and restricted to high mountains (Arnold \& Ovenden 2002). In Serbia, this species is considered rare (it inhabits less than $50 \%$ of the territory: Vukov et al. 2013), with range highly fragmented and restricted to high mountains, with some isolated populations at lower altitudes in NorthEastern Serbia and scattered lowland populations in Banat. Although the common frog occupies a wide spectrum of habitats (Kuzmin, 1999, 2013, Arnold \& Ovenden 2002), in the southern part of the range it is restricted to 
high mountains and moist habitats, near water bodies (Radovanović 1951, Kuzmin 1999, Arnold \& Ovenden 2002). In Serbia, this species inhabits mountainous and alpine coniferous forests, meadows and pastures, with some exceptions such as canyons and gorges or wetlands in the remaining forest-steppe fragments. Reproduction occurs in shallow waters, in a wide spectrum of temporary and permanent stagnant or slowly flowing waters (Kuzmin 1999). In Serbia, distribution of this species is much narrower than expected, due to severe habitat fragmentation and the species' preference for specific habitats.

Although $R$. arvalis inhabits neighbouring countries of Croatia, Hungary and Romania, with some localities being close to the Serbian border, and adequate habitats are present in the extreme northern parts of our country, until now only one literature entry (village Svetozar Miletić near Hungarian border) without later reconfirmation exists (Dely 1953, 1964, Böhme 2014). There are still no new field records for this species apart from occasional misidentification of $R$. dalmatina.

The phenomenon of vicariance is characteristic for brown frogs, due to their complex evolutionary history and allopatric speciation in isolated montane refugia (Veith et al. 2003). In Serbia, this phenomenon can be observed in north-eastern Serbia, where $R$. temporaria is vicariant with $R$. graeca, i.e. it inhabits canyons and gorges of fast-flowing montane rivers and streams at lower altitudes (Džukić 1995, Vukov et al. 2013). Rana graeca can be considered very significant for the Serbian fauna, since it is the Balkan endemic species and also reaches its northern range borders in Serbia. Peripheral populations are important in the evolutionary sense since they have a great potential for further diversification of the species (Džukić \& Kalezić 2004). Rana temporaria can be considered a glacial relict in parts of the Balkan Peninsula (Fet \& Popov 2007). Its fragmented populations in Serbia are also very important for the genetic diversity of the species and as a source of possible allopatric speciation or cryptic differentiation.

All brown frog species in Serbia are strictly protected by law ("Official Gazette of the Republic of Serbia", No. 5/2010 \& 47/2011). At the global level, all three species are considered least concern. However, at the national level, $R$. graeca and $R$. temporaria can be considered as threatened according to at least one set of criteria (Urošević \& Džukić 2015a, 2015b) (Tab. 2).

Populations of $R$. graeca which are associated with running water are especially threatened by habitat degradation - deforestation, water draining, dam building, captations and micro-hydro-electric plants. This species is also susceptible to climate change, especially temperature extremes and natural disasters such as droughts or floods (Urošević \& Džukić 2015a). 
Table 2. - Conservation status of the Serbian brown frogs according to the IUCN criteria (international), IUCN and DELH criteria (national), EU Habitats directive and Bern convention.

\begin{tabular}{lccccc}
\hline & Conservation status & & & & \\
Species & IUCN (International) & IUCN (National) & DELH(National) & Habitats & Bern \\
\hline R. dalmatina & LC & LC & LC & Annex IV & Appendix II \\
R. graeca & LC & LC & EN & Annex IV & Appendix III \\
R. temporaria & LC & NT & LC & Annex V & Appendix III \\
\hline
\end{tabular}

Populations of $R$. temporaria in Serbia are isolated due to the range fragmentation and very sensitive to anthropogenic threats, habitat degradation and climate change. Introduction of predatory fish into montane lakes can jeopardize spawn and tadpoles, and long migrations to breeding sites make Common frog vulnerable to road traffic (Urošević \& Džukić, 2015b). Protection of brown frogs and their habitats in Serbia should be of very high priority.

\section{CONCLUSIONS}

Although this study presents a systematized account on distribution of brown frogs, more methodical field research is needed in order to fill in distribution gaps and provide a more complete insight of distribution patterns. The further research should be concentrated at the northern parts of our country, for possible confirmation of the presence of $R$. arvalis and finding of more relict, lowland $R$. temporaria populations, but also in the marginal zones of the known $R$. graeca range, which could possibly be expanded further north. Since brown frogs reach peak of their annual activity in the early spring, during the reproductive season, the field research should be the most intensive from February to April, depending on the altitude.

\section{Acknowledgements}

This research was partly financed by the Ministry of Education, Science and Technological Development of Republic of Serbia - Grants No. 173025 (J.Ć., B.J., T.Č) and 173043 (A.U., Lj.T., M.A., A.G., N.T-K., M.C., T.V., T. V., G.Dž.); National Park "Kopaonik" - project Monitoring vodozemaca i gmizavaca na prostoru Nacionalnog parka Kopaonik 2018. We gratefully acknowledge Miloš Kalezić, Ana Ivanović, Miroslav Marković, Luka Rubinjoni, Aleksandar Ćetković, Boris Kryštufek, Aleksandar Stevanović and Željko Tomanović for sharing their field data and Nenad Preradović, Dejan Bogdanović, Mira Stojković, Gorana Danon, Marko 
Mirč, Neva Škrabar and Neda Bogdanović for help in the field. Field data of the late professor Gojko Pasuljević were also included in this study. Some field data were provided by the members of the Serbian Herpetological Society "Milutin Radovanović", BID "Josif Pančić", NIDSBE "Josif Pančić" and the research station "Petnica".

\section{REFERENCES}

Arnold, N., Ovenden, D. (2002): A Field Guide to the Reptiles and Amphibians of Britain and Europe. - Harper Collins Publishers, London.

Asimakopoulos, B. (2004): Rana graeca. In: Gasc, J. P., Cabela, A., CrnobrnjaIsailović, J., Dolmen, D., Grossenbacher, K., Haffner, P., Lescure, J., Martens, H., Martínez Rica, J. P., Maurin, H., Oliveira, M. E., Sofianidou, T. S., Veith, M., Zuiderwijk, A. (ed.): Atlas of Amphibians and Reptiles in Europe.: 286287. - Societas Europea Herpetologica \& Museum National d'Histoire Naturelle, Paris.

Balej, P., Jablonski, D. (2006-2015): Balcanica.info. [http://www.balcanica.cz/]

Böhme, M., Fritz, U., Kotenko, T., Džukić, G., Ljubisavljević, K., Tzankov, N., Berendonk, T. (2007): Phylogeography and cryptic variation within the Lacerta viridis complex (Lacertidae, Reptilia). - Zoologica Scripta 36(2): 119-131.

Böhme, W. (2014): Rana arvalis Nilsson, 1842 - Moorfrosch. In: Böhme, W., Grossenbacher, K. G. (ed.): Handbuch der Reptilien und Amphibien EuropasBand 5/III A: Froschlurche (Anura) III A (Ranidae I): 11-113. - Aula-Verlag, Wiebelsheim. [in German]

Bray, J. R., Curtis, J. T. (1957): An ordination of upland forest communities of southern Wisconsin. - Ecological Monographs 27(4): 325-349.

Clarke, K. R., Warwick, R. M. (1999): The taxonomic distinctness measure of biodiversity: weighting of step lengths between hierarchical levels. - Marine Ecology Progress Series 184: 21-29.

Cogălniceanu, D., Székely, P., Samoilă, C., Ruben, I., Tudor, M., Plăiaşu, R., Stănescu, F., Rozylowicz, L. (2013a): Diversity and distribution of amphibians in Romania. - ZooKeys 296: 35-57.

Cogălniceanu, D., Rozylowicz, L., Székely, P., Samoilă, C., Stănescu, F., Tudor, M., Székely, D., Iosif, R. (2013b): Diversity and distribution of reptiles in Romania. -ZooKeys 341: 49-76.

Crnobrnja-Isailović, J., Jelić, I., Stanisavljević, B., Ćosić, N. (2012): Vodozemci i gmizavci Beograda. - Ekološko društvo Endemit, Beograd.

Dely, O. G. (1953): Examen systématique et osteo-biométrique de la Rana arvalis Nilss. et de la var. wolterstorffi Fejérváry. - Annales Historico-naturales Musei Nationalis Hungarici 44 (series nova 3): 231-243. [in French]

Dely, O. G. (1964): Contribution a l'étude systematique, zoogéographique et génétique de Rana arvalis et $R$. arvalis wolterstorffi. - Acta Zoologica Hungarica 10(3-4): 309-361. 
Džukić, G., Kalezić, M. (2004): The biodiversity of amphibians and reptiles in the Balkan Peninsula. In: Griffiths, H., Krystufek, B., Reed, J. M. (ed.): Balkan Biodiversity. Pattern and Process in the European Hotspot: 1-26. - Springer, Dordrecht.

Džukić, G. (1968): New records of distribution and ecology of Rana graeca Boulenger, 1891 and Rana ridibunda Pallas, 1771 in Yugoslavia. In: Biogeography and Ecology of Bulgaria. - Monographiae Biologicae, Gent. - Arhiv bioloških nauka 20(1/2): 5-6. [In Serbian]

Džukić, G. (1972): Herpetološka zbirka Prirodnjačkog muzeja u Beogradu. [Herpetological collection of the Belgrade Museum of Natural History]. Glasnik Prirodnjačkog muzeja, Ser. B 27: 165-180. [in Serbian]

Džukić, G. (1995): Diverzitet vodozemaca (Amphibia) i gmizavaca (Reptilia) Jugoslavije, sa pregledom vrsta od međunarodnog značaja. In: Stevanović, V., Vasić, V. (ed.): Biodiverzitet Jugoslavije sa pregledom vrsta od međunarodnog značaja: 447-469. - Biološki fakultet \& Ecolibri, Beograd. [in Serbian]

Džukić, G. (2004): Žaba travnjača (Rana temporaria). - Gea 4: 44. [in Serbian]

Džukić, G., Pasuljević, G. (1979): O rasprostranjenju ljuskavog gustera Algyroides nigropunctatus (Dumeril et Bibron, 1839) (Reptilia, Lacertidae). - Biosistematika 5: 61-70. [in Serbian]

Fet, V., Popov, A. (2007):

Gasc, J. P., Cabela, A., Crnobrnja-Isailovic, J., Dolmen, D., Grossenbacher, K., Haffner, P., Lescure, J., Martens, H., Martinez Rica, J. P., Maurin, H., Oliveira, M. E., Sofianidou, T. S., Veith, M., Zuiderwijk, A. (1997): Atlas of Amphibians and Reptiles in Europe. - Societas Europea Herpetologica \& Museum National d'Histoire Naturelle, Paris.

Gaston, K. J., David, R. (1994): Hotspots across Europe. - Biodiversity Letters 2: 108-116.

Green, D. M. (1983): Evidence for chromosome number reduction and chromosomal homosequentiality in the 24-chromosome Korean frog, Rana dybowskii. Chromosoma 88: 222-226.

Green, D. M., Borkin, L. J. (1993): Evolutionary relationships of eastern Palearctic brown frogs, genus Rana: Paraphyly of the 24-chromosome species group and the significance of chromosome number change. - Zoological Journal of the Linnean Society 109: 1-25.

Grossenbacher, K. (2004): Rana temporaria. In: Gasc, J. P., Cabela, A., CrnobrnjaIsailović, J., Dolmen, D., Grossenbacher, K., Haffner, P., Lescure, J., Martens, H., Martínez Rica, J. P., Maurin, H., Oliveira, M. E., Sofianidou, T. S., Veith, M., Zuiderwijk, A. (ed.): Atlas of amphibians and reptiles in Europe: 86-287. - Societas Europea Herpetologica \& Museum National d'Histoire Naturelle, Paris.

Guillaume, C. P., Heulin, B., Beshkov, V. (1997): Biogeography of Lacerta (Zootoca) vivipara: reproductive mode and enzyme phenotypes in Bulgaria. Ecography 20(3): 240-246.

iNaturalist.org (2018a): Rana dalmatina. GBIF.org (15 ${ }^{\text {th }}$ March 2018) GBIF Occurrence Download https://doi.org/10.15468/dl.ize4xx 
iNaturalist.org (2018b): Rana graeca. GBIF.org (16 ${ }^{\text {th }}$ March 2018) GBIF Occurrence Download https://doi.org/10.15468/dl.i71k4s

Ivančević, B., Savić, S., Sabovljević, M., Niketić, M., Tomović, G., Zlatković, B., Ranđelović, V., Lakušić, D., Ćetković, A., Pavićević, D., Krpo-Ćetković, J., Crnobrnja-Isailović, J., Puzović, S., Paunović, M. (2007): Pregled vrsta Stare planine u Srbiji. In: Lakušić, D., Ćetković, A. (ed.): Biodiverzitet Stare planine u Srbiji: 159-219. - Regionalni centar za životnu sredinu za Centralnu i Istočnu Evropu, Kancelarija u Srbiji, Beograd. [in Serbian]

Jablonski, D., Jandzik, D., Gvoždik, V. (2012): New records and zoogeographic classification of amphibians and reptiles from Bosnia and Herzegovina. North-Western Journal of Zoology 8(2): 324-337.

Jetz, W., McPherson, J. M., Guralnick, R. P. (2011): Integrating biodiversity distribution knowledge: toward a global map of life. - Trends in Ecology \& Evolution 27: 151-159.

Karaman, S. (1948): Prilog herpetologiji sjeverne Srbije. - Prirodoslovna istraživanja, Zagreb 24: 51-74. [in Croatian]

Krizmanić, I., Urošević, A., Simović, A., Krstić, M., Jović, D., Ajtić, R., Anđelković, M., Slijepčević, M., Đorđević, S., Golubović, A., Žikić, V., Džukić, G. (2015): Updated distribution of the European pond turtle Emys orbicularis (Linnaeus, 1758) and its conservation issues in Serbia. - Archives of Biological Sciences 67(3): 1043-1053.

Kovačević, B. (2014): Turizam Šajkaške. - Univerzitet u Novom Sadu, PMF, Departman za geografiju, turizam i hotelijerstvo, Novi Sad. PhD Thesis

Kuzmin, S. L. (1999): The Amphibians of the Former Soviet Union. - Pensoft, Sofia-Moscow.

Kuzmin, S. L. (2013): Rana temporaria. In: AmphibiaWeb: Information on amphibian biology and conservation. - Berkeley, California. AmphibiaWeb. http://amphibiaweb.org/.

Ljubisavljević, K., Džukić, G., Vukov, T. D., Kalezić, M. L. (2014): Distribution patterns of Hermann's tortoise Testudo hermanni Gmelin,1789, in the region of former Yugoslavia (Testudines: Testudinidae). - Herpetozoa 26: 125-138.

Ljubisavljević, K., Tomović, Lj., Simović, A., Krizmanić, I., Ajtić, R., Jović, D., Urošević, A., Labus, N., Đorđević, S., Golubović, A., Anđelković, M., Džukić, G. (2015): Distribution of the Snake-eyed skink Ablepharus kitaibelii Bibron and Bory, 1833 (Squamata: Scincidae) in Serbia. - Ecologica Montenegrina 2: 247-254.

Ljubisavljević, K., Polović, L., Iković, V., Vuksanović, S., Zagora, V., Urošević, A., Tomović, Lj. (2016): New records and updated distribution of the endemic Balkan rock lizards Dinarolacerta spp. in Montenegro . - Ecologica Montenegrina 9: 46-50. [letter]

Ljubisavljević, K., Tomović, Lj., Urošević, A., Gvozdenović, S., Iković, V., Zagora, V., Labus, N. (2018): Species diversity and distribution of lizards in Montenegro. - Acta Herpetologica 13(1): 3-11.

Maričić, M., Golubović, A. (2018): Amphibia. In: Popović, M., Golubović, A., Živanović, N. (ed.): Biologer.org. https://biologer.org. (December 2018) 
Marković, J. Đ. (1970): Geografske oblasti Socijalističke Federativne Republike Jugoslavije. - Zavod za udžbenike i nastavna sredstva Srbije, Beograd.

Meiri, S. (2018): The smartphone fallacy - when spatial data are reported at spatial scales finer than the organisms themselves. - Frontiers in Biogeography 10.1: e38642.

Mesaroš, G. (2018): Portal za kartiranje biološke raznovrsnosti Srbije - BioRas. http://www.bioras.petnica.rs

Mensi, P., Lattes, A., Macario, B., Salvidio, S., Giacoma, C., Baletto, E. (1992): Taxonomy and evolution of European brown frogs. - Zoological Journal of the Linnean Society 104: 293-311.

Nöllert, A., Nöllert, C. (1992): Die Amphibien Europas. - Franckh-Kosmos Verlags-GmbH and Company, Stuttgart.

Pasuljević, G. (1966): Nova nalazišta Rana temporaria u Jugoslaviji. - Zbornik filozofskog fakulteta u Prištini 3: 453-457.

Perić, R., Stanković, M. (2005): Prilog poznavanju faune vodozemaca i gmizavaca na teritoriji opštine Apatin. In: Zbornik radova EcoIst'05 Bor 01.-04.06.2005: 43-37. [in Serbian]

Popović, E., Kostić, D. (1996): Životinjski svet Jegričke. In: Lazić, V. (ed.): Monografija Jegrička: 79-86. - Tija voda, PČESA, Novi Sad. [in Serbian]

Radovanović, M. (1951): Vodozemci i gmizavci naše zemlje. - Naučna knjiga, Beograd. [in Serbian]

Radovanović, M. (1964): Die Verbreitung der Amphibien und Reptilien in Jugoslawien. - Senckbergiana biologica 45: 553-561.

Sillero, N., Campos, J., Bonardi, A., Corti, C., Creemers, R., Crochet, P-A., Crnobrnja Isailović, J., Denoël, M., Ficetola, G. F., Gonçalves, J., Kuzmin, S., Lymberakis, P., de Pous, P., Rodríguez, A., Sindaco, R., Speybroeck, J., Toxopeus, B., Vieites, D. R., Vences, M. (2014): Updated distribution and biogeography of amphibians and reptiles of Europe. -Amphibia-Reptilia 35: 1-31.

Sindaco, R., Doria, G., Razzetti, E., Bernini, F. (2006): Atlas of Italian amphibians and reptiles (Atlante degli Anfibi e dei Rettili d'Italia). - Societas Herpetologica Italica, Edizioni Polistampa, Firenze.

Sterijovski, B. (2014): Systematic survey of amphibian and reptile fauna in the Bosilegrad region of southern Serbia. In: Sarić, M. R. (ed.): Flora Srbije 1. - Srpska akademija nauka i umetnosti, Beograd. - Biologia Serbica 36(1-2): 65-68.

Stevanović, V. (1992): Floristička podela teritorije Srbije sa pregledom viših horiona i odgovarajućih flornih elemenata.: 47-56.

Szabolcs, M., Mizsei, E., Jablonski, D., Vági, B., Master, B., Végvári, Z., Lengyel, S. (2017): Distribution and diversity of amphibians in Albania: new data and foundations of a comprehensive database. - Amphibia - Reptililia 38: 435-448.

Tadijan, Z., Mikeš, M. (1984): Herpetološka osmatranja na Fruškoj Gori. In: Zbornik studentskih radova, Institut za biologiju PMF: 41-50. - Prirodnomatematički fakultet, Novi Sad. [in Serbian]

Tomović, Lj., Ajtić, R., Ljubisavljević, K., Urošević, A., Jović, D., Krizmanić, I., Labus, N., Đorđević, S., Kalezić, M. L., Vukov, T., Džukić, G. (2014): 
Reptiles in Serbia- Distribution and Diversity Patterns. - Bulletin of the Natural History Museum 7: 129-158.

Tomović, Lj., Urošević, A., Ajtić, R., Krizmanić, I., Simović, A., Labus, N., Jović, D., Krstić, M., Đorđević, S., Anđelković, M., Golubović, A., Džukić, G. (2015): Contribution to the Knowledge of Distribution of Colubrid Snakes in Serbia. - Ecologica Montenegrina 2(3): 162-186.

Tomović, Lj., Timotijević, M., Ajtić, R., Krizmanić, I., Labus, N. (2018): Contribution to the herpetofauna of Serbia - Distribution of Reptiles in Kosovo and Metohija Province. - University Thought 8(2): 1-6.

Urošević, A., Džukić, G. (2015a): Rana graeca. In: Kalezić, M., Tomović, Lj., Džukić, G. (ed.): Crvena knjiga faune Srbije I: Vodozemci: 186-191. Univerzitet u Beogradu - Biološki fakultet i Zavod za zaštitu prirode Srbije, Beograd.

Urošević, A., Džukić, G. (2015b): Rana temporaria. In: Kalezić, M., Tomović, Lj., Džukić, G. (ed.): Crvena knjiga faune Srbije I: Vodozemci: 192-198. Univerzitet u Beogradu - Biološki fakultet i Zavod za zaštitu prirode Srbije, Beograd.

Urošević, A., Ljubisavljević, K., Tomović, Lj., Krizmanić, I., Ajtić, R., Simović, A., Labus, N., Jović, D., Golubović, A., Anđelković, M., Džukić, G. (2015): Contribution to the Knowledge of Distribution and Diversity of Lacertid Lizards in Serbia. - Ecologica Montenegrina 2 (3): 197-227.

Urošević, A., Tomović, Lj., Ajtić, R., Simović, A., Džukić, G. (2016): Alterations in the Reptilian Fauna of Serbia: Introduction of Exotic and Anthropogenic Range Expansion of Native Species. - Herpetozoa 28(3/4): 115-132.

Valakos, E. D., Pafilis, P., Sotiropoulos, K., Lymberakis, P., Maragous, P., Foufopoulos, J. (2008): The amphibians and reptiles of Greece. - Chimaira, Frankfurt am Main.

Veith, M., Kosuch, J., Vences, M. (2003): Climatic oscillations triggered postMessinian speciation of Western Palearctic brown frogs (Amphibia, Ranidae). - Molecular Phylogenetics and Evolution 26: 310-327.

Vigna Taglianti, A., Audisio, P., Biondi, M., Bologna, M., Carpaneto, G., De Biase, A., Fattorini, S., Piattella, E., Sindaco, R., Venchi, A., Zapparoli, M. (1999): A proposal for a chorotype classification of the Near East fauna, in the framework of the western Palearctic region.: 31-59. 20

Vukov, T., Kalezić, M. L., Tomović, Lj., Krizmanić, I., Jović, D., Labus, N., Džukić, G (2013): Amphibians in Serbia - distribution and diversity patterns. Bulletin of the Natural History Museum 6: 90-112.

Wallace, A. R. (1852): On the monkeys of the Amazon. - Annals and Magazine of Natural History 14: 451-454.

Warwick, R. M., Clarke, K. R. (1995): New 'biodiversity' measures reveal a decrease in taxonomic distinctness with increasing stress. - Marine Ecology Progress Series 129: 301-305.

Zachos, F. E., Habel, J. C. (2011): Biodiversity Hotspots - Distribution and Protection of Conservation Priority Areas. - Springer-Verlag, Berlin-Heidelberg. 


\title{
SUPPORTING INFORMATION
}

Online Appendices:

Appendix 1. - Unpublished records.

Appendix 2. - Previously published records.

Appendix 3. - Online records.

\section{ДИСТРИБУЦИЈА И ДИВЕРЗИТЕТ МРКИХ ЖАБА (RANA SPP., ANURA, AMPHIBIA) У СРБИЈИ}

\author{
Р Е 3 И М Е
}

АЛЕКСАНДАР УРОШЕВИЋ, ЉИЉАНА ТОМОВИЋ, ИМРЕ КРИЗМАНИЋ, МАРКО АНЪЕЛКОВИЋ, АНА ГОЛУБОВИЋ, МАРКО МАРИЧИЋ, РАСТКО АЈТИЋ, ЈЕЛЕНА ЋОРОВИЋ, ТИЈАНА ЧУБРИЋ, НАТАША ТОМАШЕВИЋКОЛАРОВ, МИЛЕНА ЦВИЈАНОВИЋ, ТАҢА ВУКОВ, БОГДАН ЈОВАНОВИЋ, ТИЈАНА ВУЧИЋ, МАЈА АЈДУКОВИЋ, ИВАН ТОТ, БОЈАНА НАДАЖДИН, НЕНАД ЛАБУС, ГЕОРГ ЏУКИЋ

У овом раду приказујемо ажуриране податке о дистрибуцији све три врсте мрких жаба (Rana spp.) које насељавају Србију. Коришћени су необјављени подаци прикупљени током теренских истраживања као и претходно објављени подаци сакупљени у литератури или на Интернету. Од три врсте присутне у Србији, Rana dalmatina је најшире распрострањена, присутна у сва три рељефна региона као и у свим биогеографским регионима. Rana graeca је ограничена на сталне брзе реке или потоке у планинско-котлинском региону и достиже своје северне границе ареала у Србији. Rana temporaria је најређа међу ове три врсте, са фрагментисаним ареалом ограниченим на високе планине или неколико изолованих низијских популација, а у североисточној Србији је викарна са $R$. graeca у кањонима и клисурама планинских река. Присуство врсте $R$. arvalis се спомиње у литератури али није потврђено током каснијих теренских истраживања тако да је и даље можемо сматрати само као потенцијалну врсту за батрахофауну Србије. Састав фауне мрких жаба Србије идентичан је оном Албаније, Босне и Херцеговине, Бугарске, Грчке, Македоније и Црне Горе док се донекле разликује од фауне Мађарске и Румуније и најразличитији је 
Bulletin OF the Natural History Museum, 2018, 11: 227-245. 245

од фауне Хрватске и Словеније. Мрке жабе Србије припадају европском ( $R$. temporaria) и јужноевропском хоротипу ( $R$. dalmatina, $R$. graeca). Све врсте мрких жаба присутне или потенцијално присутне у Србији као и њихова станишта препознати су као конзервациони приоритети. 